\title{
Gastrointestinal parasites in wild and exotic animals from a Zoobotanical Park in
}

\section{Northeast of Brazil}

\author{
Parasitos gastrintestinais em animais silvestres e exóticos de um Parque Zoobotânico no Nordeste \\ do Brasil
}

Parásitos gastrointestinales en animales salvajes y exóticos de un Parque Zoobotánico en el Noreste

de Brasil

Received: 09/30/2021 | Reviewed: 10/09/2021 | Accept: 10/17/2021| Published: 10/20/2021

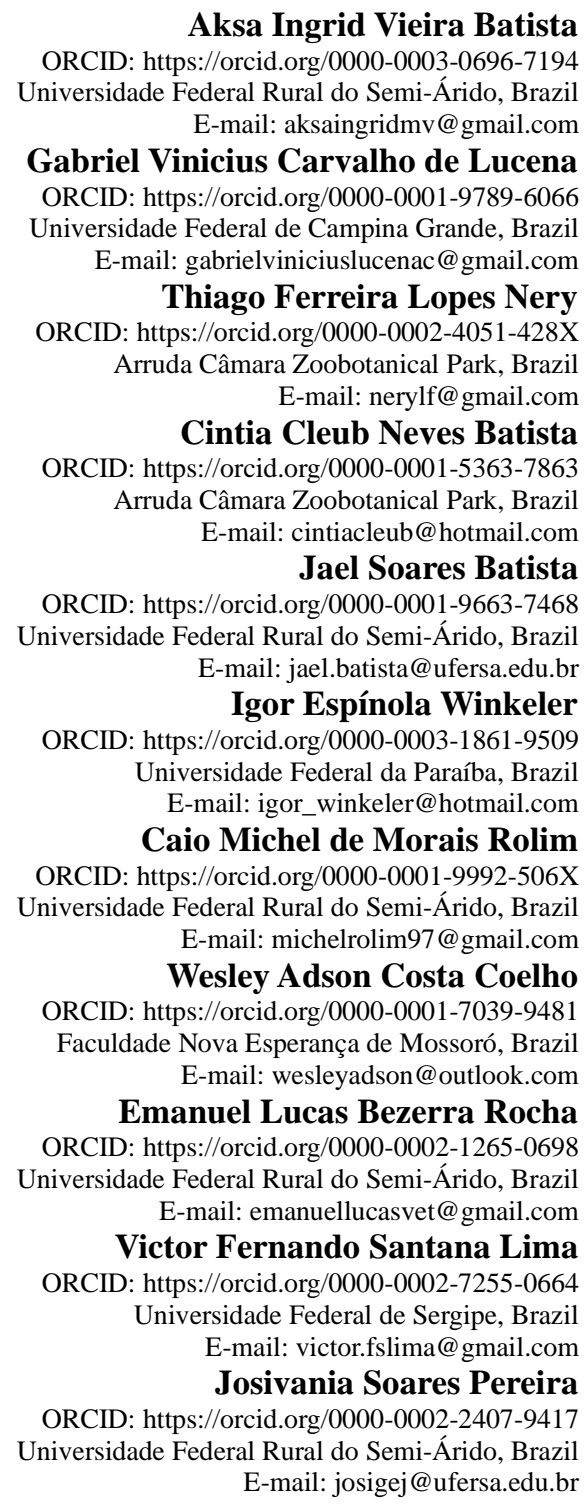

\begin{abstract}
One of the obstacles for ex situ conservation of wild and exotic animals are the diseases that affect them in captivity and, among them, the endoparasitoses, which are very frequent. The objective of this study is to report the occurrence of endoparasites in the fecal samples of animals from the Arruda Câmara Zoobotanical Park, at João Pessoa, Paraiba State, Brazil, as well as to identify significant statistical differences between the percentages of each parasite species found. To this end, 66 fecal samples were obtained from 50 species of animals including mammals, birds, and reptiles. Statistical differences between the percentages of each parasite species were obtained using the binomial test at $5 \%$
\end{abstract}


significance level. A total of 54.5\% (36/66) of the fecal samples were positive ( $\mathrm{p}=0.539)$, among which $80.5 \%(29 / 36)$ presented nematodes, followed by cestodes $19.4 \%$ (07/36), protozoans $13.9 \%(05 / 36)$, and mites $16.7 \%$ (06/36). This study reports for the first time the association of Balantidium sp. with Tapirus terrestris, Bertiella sp. with Alouatta caraya, Hymenolepis spp., and Aspiculuris spp. as spurious parasites in reptiles; and Entamoeba coli and Eimeria spp. with Iguana iguana in the northeastern part of the country. This study provides knowledge about some of the endoparasites that may occur in zoos in the northeastern region of the country, as well as in expanding the ecological data on wild and exotic animals.

Keywords: Birds; Helminths; Mammals; Mini-FLOTAC; Protozoans.

\title{
Resumo
}

Um dos obstáculos da conservação ex situ de animais silvestres e exóticos são as doenças que os acometem em cativeiro e, dentre elas, as endoparasitoses são muito frequentes. O objetivo deste trabalho é relatar a ocorrência de endoparasitos em amostras fecais de animais do Parque Zoobotânico Arruda Câmara, em João Pessoa, Paraíba, Brasil, bem como identificar diferenças estatísticas significativas entre os percentuais de cada espécie de parasito encontrada. Para tanto, foram obtidas 66 amostras fecais de 50 espécies de animais, entre mamíferos, aves e répteis. As diferenças estatísticas entre as porcentagens de cada espécie de parasito foram obtidas pelo teste binomial com nível de significância de $5 \%$. Um total de 54,5\% (36/66) das amostras fecais foram positivas ( $\mathrm{p}=0,539)$, entre as quais $80,5 \%$ (29/36) eram de nematoides, seguidos de cestoides 19,4\% (07/36), protozoários 13,9\% (05/36), e ácaros 16,7\% (06/36). Este estudo relata pela primeira vez a associação de Balantidium sp. em Tapirus terrestris, Bertiella sp. em Alouatta caraya, Hymenolepis spp. e Aspiculuris spp. como parasitas espúrios em répteis; e Entamoeba coli e Eimeria spp. com Iguana Iguana no nordeste do país. Este estudo fornece conhecimento sobre alguns dos endoparasitos que podem ocorrer em zoológicos da região Nordeste do país, bem como auxilia na ampliação dos dados ecológicos sobre animais silvestres e exóticos.

Palavras-chave: Aves; Helmintos; Mamíferos; Mini-FLOTAC; Protozoários.

\begin{abstract}
Resumen
Uno de los obstáculos para la conservación ex situ de los animales silvestres y exóticos son las enfermedades que los afectan en cautiverio y, entre ellas, las endoparasitosis, que son muy frecuentes. El objetivo de este estudio es reportar la ocurrencia de endoparásitos en las muestras fecales de animales del Parque Zoobotánico Arruda Câmara, en João Pessoa, Estado de Paraíba, Brasil, así como identificar diferencias estadísticas significativas entre los porcentajes de cada especie parasitaria encontrada. Para ello, se obtuvieron 66 muestras fecales de 50 especies de animales, incluidos mamíferos, aves y reptiles. Las diferencias estadísticas entre los porcentajes de cada especie de parásito se obtuvieron mediante la prueba binomial al nivel de significancia del 5\%. El 54,5\% (36/66) de las muestras fecales resultaron positivas $(\mathrm{p}=0,539)$, de las cuales el 80,5\% (29/36) presentaron nematodos, seguido de los cestodos 19,4\% (07/36), protozoos 13,9\% (05 / 36) y ácaros 16,7\% (06/36). Este estudio reporta por primera vez la asociación de Balantidium sp. con Tapirus terrestris, Bertiella sp. con Alouatta caraya, Hymenolepis spp. y Aspiculuris spp. como parásitos espurios en reptiles; y Entamoeba coli y Eimeria spp. con Iguana iguana en el noreste del país. Este estudio brinda conocimiento sobre algunos de los endoparásitos que pueden ocurrir en los zoológicos de la región noreste del país, así como en la ampliación de los datos ecológicos sobre animales silvestres y exóticos.
\end{abstract}

Palabras clave: Aves; Helmintos; Mamíferos; Mini-FLOTAC; Protozoos.

\section{Introduction}

Brazil is the fifth largest country in the world with great diversity of animal species. It is estimated that approximately $20 \%$ of all animal species live in this region, in different biomes such as the Atlantic Forest, Pampa, Cerrado, Pantanal, Amazon, and the Caatinga. Among the various types of association existing in nature, parasitism is common, and it is well known that at least half of all the animal taxa is parasitic (Instituto Chico Mendes de Conservação da Biodiversidade, 2017; Lima et al., 2017).

One of the obstacles for ex situ conservation of wild and exotic animals are the diseases that affect them in captivity. Among them, gastrointestinal endoparasitoses are very frequent, and the disease may present itself with or without evident clinical signs. The costs to the host may be negligible, substantial, or even unbearable, depending on the number of parasites, the species, the level of severity of the lesions they inflict, as well as on the vigor and nutritional status of the host. Knowing this, the costs of parasitism may include the loss of resources extracted by the parasite directly from the host and the energy spent by the host to maintain its vital actions. The consequences of these associations are usually linked to the decreased 
reproductive and survival capacity of the hosts, therefore affecting their mortality and birth rates (Oliveira et al., 2011; Reed et al., 2012; Lima et al., 2017).

Parasitic diseases present a high prevalence in captive wild and exotic animals, since there is a high environmental contamination that result from keeping animals in confined areas. In addition, the stress caused by the captivity may decrease the resistance of these animals to parasitic diseases. In cases in which animals show signs of parasitic disease, these may range from lack of appetite, weight loss, disorders in the gastrointestinal tract, anemia, and hyperthermia, among others (Fagiolini et al., 2010; Oliveira et al., 2011; Reed et al., 2012).

Among the endoparasites that affect zoo animals, there are also many zoonotic species, therefore representing a public health problem, especially for the professionals and keepers who manage these specimens. Many nematodes that can be found in these animals are of medical concern, such as Ancylostoma sp., which can cause cutaneous larva migrans; and Toxocara sp., responsible for visceral larva migrans, ocular larva migrans, and cerebral toxocariasis in humans; both being endoparasites widely reported in carnivores. Further, it is also important to highlight the presence of cestodes such as Hymenolepis spp., Taenia spp., and Bertiella spp., which can be found both in primates and rodents, or even as spurious parasites in reptiles, for example. All of these parasites present medical interest and may cause diarrhea, abdominal pain, irritability, and weight loss (Fagiolini et al., 2010; Oliveira et al., 2011; Reed et al., 2012; Lima et al., 2017).

Thus, these sites should have efficient diagnostic techniques to carry out coproparasitological research in wild and exotic animals in zoos. Among these techniques, the Mini-FLOTAC allows the simultaneous diagnosis of helminth eggs/larvae and oocysts/cysts of protozoans, offering an advantage over other coproparasitological techniques. In addition, Mini-FLOTAC also allows the diagnosis of yeasts, such as Macrorhabdus ornithogaster, in bird feces (Cringoli et al., 2017).

All this knowledge provides new data on the parasites of these host species, contributing to a better understanding of the parasite-host relationships that occur in these environments. In addition, it also helps in the implementation of management, treatment, and control activities for the parasites that occur in these host species, contributing to the reduction in the number of zoonotic diseases in these parks (Fagiolini et al., 2010).

The present work aimed to report the occurrence of endoparasites in the feces of captive animals and in the animals that attended the Arruda Câmara Zoobotanical Park, João Pessoa, Paraíba, Brazil, as well as to identify the statistical differences between the percentages of the parasites found.

\section{Methodology and Case Description}

\section{Ethical aspects}

The project was submitted to the Ethics Committee on the Use of Animals in Research of the Universidade Federal Rural do Semi-Arido (UFERSA) (CEUA-UFERSA) and approved ( $\mathrm{N}^{\circ}$ of opinion 11/2020). All the handling procedures of the animals followed the specific guidelines of the Brazilian College of Animal Experimentation.

\section{Study area}

The research was conducted at the Arruda Câmara Zoobotanical Park (ACZP), (CNPJ: 08.806.721/0001-03). This park is registered at the Brazilian Institute for the Environment and Renewable Natural Resources under the Registration No. 236567. It is popularly known as Bica, being located between the coordinates $292670 \mathrm{mE}$ and $293330 \mathrm{mE}$, and between $9213107 \mathrm{mN}$ and $9214100 \mathrm{mN}$, more precisely in the northern part of the municipality of João Pessoa. This park is set in a 26.4hectare Atlantic Forest fragment, being the home to native and exotic flora and fauna species, distributed among different areas available for visitation (Figure 1). 
Figure 1 - Map of the Arruda Câmara Zoobotanical Park (ACZP) collection region, Paraíba State, Brazil.

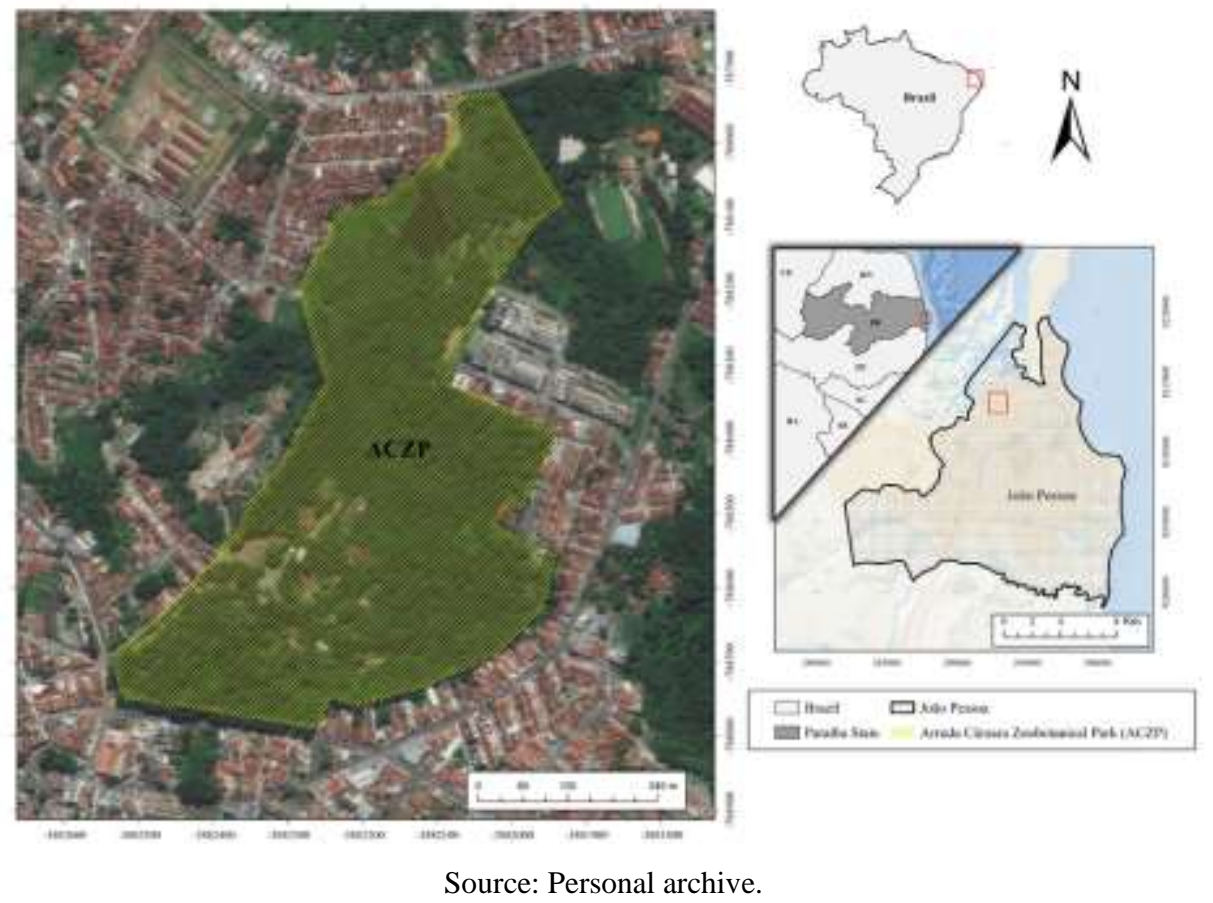

\section{Sampled animals}

We analyzed 66 fecal samples from animals that were kept at the ACZP, João Pessoa-PB, as well as from wild animals that were attended, totaling 50 species. The fecal samples spontaneously eliminated by the animals were collected individually or in pools from the floor of the enclosure to avoid stressing the hosts and endangering the handlers of the animals.

Among the animals, the samples were collected from carnivorous felids such as Panthera leo ( $\mathrm{n}=1)$, Puma concolor $(\mathrm{n}=2)$, Puma yagouroundi $(\mathrm{n}=1)$, and Leopardus pardalis $(\mathrm{n}=3)$; procionids like Nasua nasua $(\mathrm{n}=6)$ and Procyon cancrivorus $(\mathrm{n}=5)$; primates like Sapajus flavius $(\mathrm{n}=5)$, Sapajus libidinosus $(\mathrm{n}=7)$, Sapajus spp. $(\mathrm{n}=3)$, Saimiri sciureus $(\mathrm{n}=1)$, Alouatta caraya $(\mathrm{n}=2)$, and Chlorocebus aeothiops $(\mathrm{n}=2)$; artiodactyla such as Pecari tajacu $(\mathrm{n}=5)$; perissodactyla like Tapirus terrestris $(\mathrm{n}=1)$; birds like Anodorhynchus hyacinthinus $(\mathrm{n}=1)$, Ara ararauna $(\mathrm{n}=1)$, Ara chloropterus $(\mathrm{n}=1)$, Amazona aestiva $(\mathrm{n}=1)$, Turdus sp. $(\mathrm{n}=2)$, Cacicus cela $(\mathrm{n}=1)$, Crax fasciolata $(\mathrm{n}=2)$, Patagioenas picazuro $(\mathrm{n}=1)$, and Rupornis magnirostris $(\mathrm{n}=1)$; and the reptiles Pantherophis guttatus $(\mathrm{n}=7)$, Bothrops erythromelas $(\mathrm{n}=1)$, Salvator merianae $(\mathrm{n}=1)$, Iguana iguana $(\mathrm{n}=1)$, Chelonoidis sp. $(\mathrm{n}=1)$, Chelonoidis carbonaria $(\mathrm{n}=1)$, and Chelonoidis denticulata $(\mathrm{n}=1)$ (Table 1).

Table 1 - Species of animals captive and cared for at the Arruda Câmara Zoobotanical Park (ACZP) used in the present study. NA: number of animals.

\begin{tabular}{lll}
\hline Common host name & Scientific host name & NA \\
\hline & Class Mammalia & \\
& Order Carnivora & \\
& Family Felidae & 1 \\
Lion & Panthera leo & 1 \\
Jaguar & Panthera onca & 2 \\
Cougar & Puma concolor & 1 \\
Jaguarundi & Puma yagouaroundi & 1 \\
Oncilla & Leopardus tigrinus & 3 \\
Ocelot & Leopardus pardalis & \\
& Family Procyonidae & 6 \\
South American coati & Nasua nasua & 5 \\
Crab-eating racoon & Procyon cancrivorus &
\end{tabular}


Tayra

Neotropical otter

Crab-eating fox

Blond capuchin

Black-striped capuchin

Capuchin

Common marmoset

Common squirrel monkey

Black howler

Three-striped night monkey

Grivet

Rhesus macaque

Collared pecary

Brown brocket

South American tapir

Brown-throated sloth

Hyacinth macaw

Blue-and-yellow macaw

Red-and-green macaw

Turquoise-fronted amazon

Red-shouldered macaw

White-eyed parakeet

Thrush

Yellow-rumped cacique

Typical guans

Bare-faced curassow

Picazuro pigeon

Roadside Hawk

Magnificent frigatebird

Domestic goose
Eira barbara

Lontra longicaudis

1

Family Canidae

Cerdocyon thous

Order Primates

Family Cebidae

Sapajus flavius

Sapajus libidinosus

Sapajus spp.

Callithrix jacchus

Saimiri sciureus

Family Atelidae

Alouatta caraya

Family Aotidae

Aotus trivirgatus

Family Cercopithecidae

Chlorocebus aeothiops

Macaca mulatta

Order Artiodactyla

Family Tayassuidae

Pecari tajacu

Family Cervidae

Mazama gouazoupira

Order Perissodactyla

Family Tapiridae

Tapirus terrestris

Order Pilosa

Family Bradypodidae

Bradypus variegatus

Class Aves

Order Psittaciformes

Family Psittacidae

Anodorhynchus hyacinthinus

Ara ararauna

Ara chloropterus

Amazona aestiva

Diopsittaca nobilis cumanensis

Psittacara leucophthalmus

Order Passeriformes

Family Turdidae

Turdus sp.

Family Icteridae

Cacicus cela

Order Galliformes

Family Cracidae

Penelope sp.

Crax fasciolata

Order Columbiformes

Family Columbidae

Patagioenas picazuro

Order Accipitriformes

Family Accipitridae

Rupornis magnirostris

Order Pelecaniformes

Family Fregatidae

Fregata magnificens

Order Anseriformes

Family Anatidae

Anser sp.

Order Piciformes

Family Ramphastidae 


\begin{tabular}{|c|c|c|}
\hline White-throated toucan & $\begin{array}{l}\text { Ramphastos tucanus } \\
\text { Order Cariamiformes } \\
\text { Family Cariamidae }\end{array}$ & 1 \\
\hline Red-legged seriema & $\begin{array}{l}\text { Cariama cristata } \\
\text { Class Lepidosauria } \\
\text { Order Squamata } \\
\text { Family Colubridae }\end{array}$ & 2 \\
\hline Corn snake & $\begin{array}{l}\text { Pantherophis guttatus } \\
\text { Family Boidae }\end{array}$ & 7 \\
\hline Rainbow boa & Epicrates assisi & 1 \\
\hline India rock python & Pithon molurus & 1 \\
\hline Green anaconda & $\begin{array}{l}\text { Eunectes murinus } \\
\text { Family Viperidae }\end{array}$ & 1 \\
\hline Caatinga lancehead & $\begin{array}{l}\text { Bothrops erythromelas } \\
\text { Family Teiidae }\end{array}$ & 1 \\
\hline Argentine black and white tegu & $\begin{array}{l}\text { Salvator merianae } \\
\text { Family Iguanidae }\end{array}$ & 1 \\
\hline Green iguana & $\begin{array}{l}\text { Iguana iguana } \\
\text { Class Archelosauria } \\
\text { Order Testudines } \\
\text { Family Testudinidae }\end{array}$ & 1 \\
\hline Tortoise & Chelonoidis sp. & 1 \\
\hline Red-footed tortoise & Chelonoidis carbonaria & 1 \\
\hline Yellow-footed tortoise & Chelonoidis denticulata & 1 \\
\hline
\end{tabular}

Source: Personal archive.

\section{Laboratory Analysis}

The fecal samples were preserved in 5\% formalin and sent to the Laboratory of Animal Parasitology (LAP) at the Universidade Federal Rural do Semi-Árido (UFERSA) for coproparasitological analysis. The techniques used were the direct method (Hoffmann, 1987), zinc sulfate flotation (Willis, 1921), spontaneous sedimentation (Hoffmann et al., 1934), and MiniFLOTAC (Cringoli et al., 2012; 2013; 2017). The Mini-FLOTAC technique (Cringoli et al., 2012; 2013; 2017) was used to determine the parasite load since it is a quantitative method for obtaining EPG (eggs per gram of stool), OPG (oocysts per gram of stool), CPG (cysts per gram of stool), LPG (larvae per gram of stool), and TPG (trophozoites per gram of stool) values, with 10 as the conversion factor.

Photographs of the endoparasites found were taken with a digital camera and the classification was made according to specific literature, such as Foreyt (2002).

\section{Statistical analysis}

The data were collected in a table and then transferred to the statistical program SPSS (Statistical Page for Social Sciences) version 23.0. They were expressed as simple frequency and percentage of parasites and compared among them for significant statistical differences using the binomial test for homogeneous proportions. The significance level was set at 5\%.

\section{Results}

Of the total number of analyzed fecal samples $(\mathrm{n}=66), 54.5 \%(36 / 66)$ were positive $(\mathrm{p}=0.539)$, with single parasitism being observed in $52.8 \%(\mathrm{n}=19)$ of the animals and multiple parasitism in $47.2 \%(\mathrm{n}=17)$. Of these 36 positive samples, $44.4 \%$ were from mammals, in which $37.4 \%$ corresponded to the order Carnivora; $50.0 \%$ to the order Primates; $6.3 \%$ were from the order Artiodactyla; and $6.3 \%$ from Perissodactyla. Birds corresponded to $25.0 \%$ of the positive samples, with $44.5 \%$ Psittaciformes, 22.2\% Passeriformes, 11.1\% Galliformes, 11.1\% Columbiformes, and 11.1\% Accipitriformes. Finally, reptiles represented $30.6 \%$ of the positive samples, with $75.0 \%$ belonging to the order Squamata and $25.0 \%$ to the order Testudines (Table 2). 


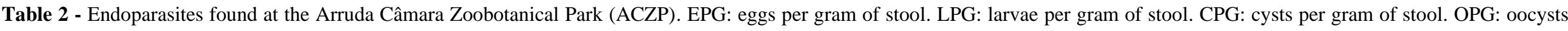
per gram of stool. TPG: trophozoites per gram of stool.

\begin{tabular}{|c|c|c|}
\hline Host & Origin & Result \\
\hline Panthera leo & ACZP & Eggs of Toxascaris leonina \\
\hline Puma concolor & ACZP & Eggs of Toxocara sp. (40 EPG) \\
\hline Puma yagouaroundi & ACZP & Eggs of Toxocara sp. (400 EPG) \\
\hline Leopardus pardalis & Free-living & Eggs of Syphacia sp. \\
\hline Nasua nasua & ACZP & Eggs of Strongyloides sp. (10 EPG) and Rhabditida-type larvae (10 LPG). \\
\hline Procyon cancrivorus & ACZP & Egg of Strongylida-type \\
\hline Sapajus flavius & ACZP & Cestoda-type eggs (70 EPG), eggs of Strongyloides sp., Ancylostomatidae-type eggs, and Rhabditida-type larvae (30 LPG). \\
\hline \multirow[t]{3}{*}{ Sapajus libidinosus } & ACZP & Eggs of Strongyloides sp. (200 EPG), Ancylostomatidae-type eggs (30 EPG), and Rhabditida-type larvae (70 LPG). \\
\hline & ACZP & Eggs of Strongyloides sp. (240 EPG), Ancylostomatidae-type eggs (50 EPG), and Rhabditida-type larvae (50 LPG). \\
\hline & ACZP & Eggs of Strongyloides sp. (50 EPG), Ancylostomatidae-type eggs (20 EPG), and Rhabditida-type larvae. \\
\hline Sapajus spp. & ACZP & Eggs of Strongyloides sp. (840 EPG), Ancylostomatidae-type eggs (120 EPG), and Rhabditida-type larvae (20 LPG). \\
\hline Saimiri sciureus & ACZP & Nematoda-type eggs. \\
\hline Alouatta caraya & ACZP & Eggs of Bertiella spp. (110 EPG). \\
\hline Chlorocebus aeothiops & ACZP & Eggs of Strongyloides sp. (140 EPG), eggs of Trichuris sp. and Rhabditida-type larvae. \\
\hline Pecari tajacu & ACZP & Eggs of Strongyloides sp. (180 EPG), Strongylida-type eggs (110 EPG) and Rhabditida-type larvae (190 LPG). \\
\hline Tapirus terrestris & ACZP & Trophozoites and cysts of Balantidium sp. (470 CPG) and non-sporulated coccidia (280 OPG). \\
\hline Anodorhynchus hyancinthinus & ACZP & Eggs of Capillaria spp. \\
\hline Ara ararauna & ACZP & Eggs of Capillaria spp. (180 EPG). \\
\hline Ara chloropterus & ACZP & Eggs of Capillaria spp. (140 EPG). \\
\hline Amazona aestiva & ACZP & Eggs of Capillaria spp. (960 EPG). \\
\hline Turdus sp. & Free-living & Strongylida-type eggs. \\
\hline Cacicus cela & Free-living & Oocysts and non-sporulated coccidia (30 OPG), Isospora sp. (20 OPG) and Rhabditida-type larvae (10 LPG). \\
\hline Crax fasciolata & ACZP & Ascaridoidea-type eggs (30 EPG) and eggs of Capillaria spp. \\
\hline Patagioenas picazuro & $\mathrm{ACZP}$ & Eggs of Capillaria spp. (240 EPG). \\
\hline Rupornis magnirostris & ACZP & Eggs of Trichuris sp. (30 EPG). \\
\hline \multirow[t]{6}{*}{ Pantherophis guttatus } & ACZP & Eggs of Aspiculuris sp. (20 EPG) and mite eggs. \\
\hline & ACZP & Eggs of Hymenolepis sp., eggs of Aspiculuris sp., and mite eggs. \\
\hline & ACZP & Eggs of Hymenolepis sp. (70 EPG), eggs of Aspiculuris sp. (50 EPG), and mite eggs. \\
\hline & $\mathrm{ACZP}$ & Eggs of Hymenolepis sp. (10 EPG) and mite eggs. \\
\hline & ACZP & Eggs of Hymenolepis sp. (20 EPG). \\
\hline & ACZP & Eggs of Hymenolepis sp. \\
\hline Bothrops erythromelas & ACZP & Eggs of Aspiculuris sp. (20 EPG), mite eggs, and mites (Myocoptes musculinus). \\
\hline Salvator merianae & ACZP & Eggs of strongylids (60 EPG), Rhabditida larvae (100 LPG), Eggs of Strongyloidoidea (30 EPG), and mite eggs. \\
\hline Iguana iguana & Free-living & Cysts of Entamoeba coli (170 CPG), non-sporulated coccidia (130 OPG), and Eimeria sp. (120 OPG). \\
\hline Chelonoidis sp. & ACZP & $\begin{array}{c}\text { Cysts (50 CPG) and trophozoites (40 TPG) of Balantidium spp., cysts and trophozoites (30 TPG) of Nyctotherus spp., Strongylida-type eggs (30 EPG), } \\
\text { and Rhabditida-type larvae (30 LPG). }\end{array}$ \\
\hline Chelonoidis denticulata & ACZP & $\begin{array}{c}\text { Cysts (150 CPG) and trophozoites (2000 TPG) of Balantidium spp., cysts (380 CPG) and trophozoites (440 TPG) of Nyctotherus spp., Strongylida-type } \\
\text { eggs (30 EPG), and Rhabditida-type larvae (60 LPG). }\end{array}$ \\
\hline
\end{tabular}

Source: Personal archive. 
In the positive samples, the highest prevalence ( $\mathrm{p}=0.001$ ) was of Nematoda, with $80.5 \%$ (29/36). Among these worms, parasitic forms of the orders Strongylida (27.5\%), Trichinellida (27.5\%), and Rhabditida (37.9\%) were found. Due to the similarity between the eggs of the order Strongylida, and since we used only morphological traits in this study, we decided in some cases to make an approximate identification of specimens from Ancylostomatidae and Strongylida. Trichinellida eggs of the genera Capillaria and Trichuris were observed. Among the Rhabditida, the following parasites were found: rhabditoid larvae; eggs of the superfamily Ascarididoidea, such as eggs of Toxascaris leonina, Toxocara sp, and unidentified eggs obtained from Crax fasciolata (suggested as Heterakis spp. or Ascaridia spp.); eggs of the superfamily Oxyuroidea, such as eggs of Syphacia sp. and Aspiculuris sp.; and eggs of the superfamily Strongyloidoidea, in Salvator merianae (suggested as Strongyloides sp. or Rhabdias sp.). In addition, eggs of Nematoda were found in Saimiri sciureus (Table 2).

Cestodes were found in 19.4\% of the animals analyzed (07/36), all of them belonging to the order Cyclophyllidea. Thus, we recovered eggs from the Hymenolepididae family, such as Hymenolepis spp; from the Anoplocephalidae family, such as Bertiella spp; and eggs of unidentified Cestoda (suggested as Hymenolepis spp. and Paratriotaenia spp.) (Table 2, Figure 2). 
Figure 2 - Eggs, oocysts, trophozoites and cysts found at the Arruda Câmara Zoobotanical Park (ACZP), Objective (40x). A Egg of Bertiella spp. in Alouatta caraya; B - Eggs of Capillaria spp. in Amazona aestiva; C - Unsporulated oocyst of coccidia in Tapirus terrestris; D - Unsporulated oocyst of coccidia in Cacicus cela; E - Isospora sp. in Cacicus cela; F - Strongylidatype eggs in Chelonoidis sp.; G - Ancylostomatidae-type eggs in Sapajus libidinosus; $\mathrm{H}$ - Egg of Trichuris spp. in Rupornis magnirostris; I - Egg of Strongyloides spp. on Pecari tajacu; J - Egg of Syphacia spp. on Leopardus pardalis; K - Egg of Hymenolepis spp. on Pantherophis guttatus; L - Egg of Aspiculuris spp. on Pantherophis guttatus; M - Eggs of Toxocara spp. on Puma yagouaroundi; N - Cyst of Nyctotherus spp. on Chelonoidis sp.; O - Trophozoites of Nyctotherus spp. in Chelonoidis carbonaria; P - Cestoda-type eggs in Sapajus flavius; Q - Cyst of Balantidium spp. in Chelonoidis sp.; R - Trophozoites of Balantidium spp. in Chelonoidis spp.; S - Ascaridoidea-type egg in Crax fasciolata; T - Entamoeba coli cyst in Iguana iguana.

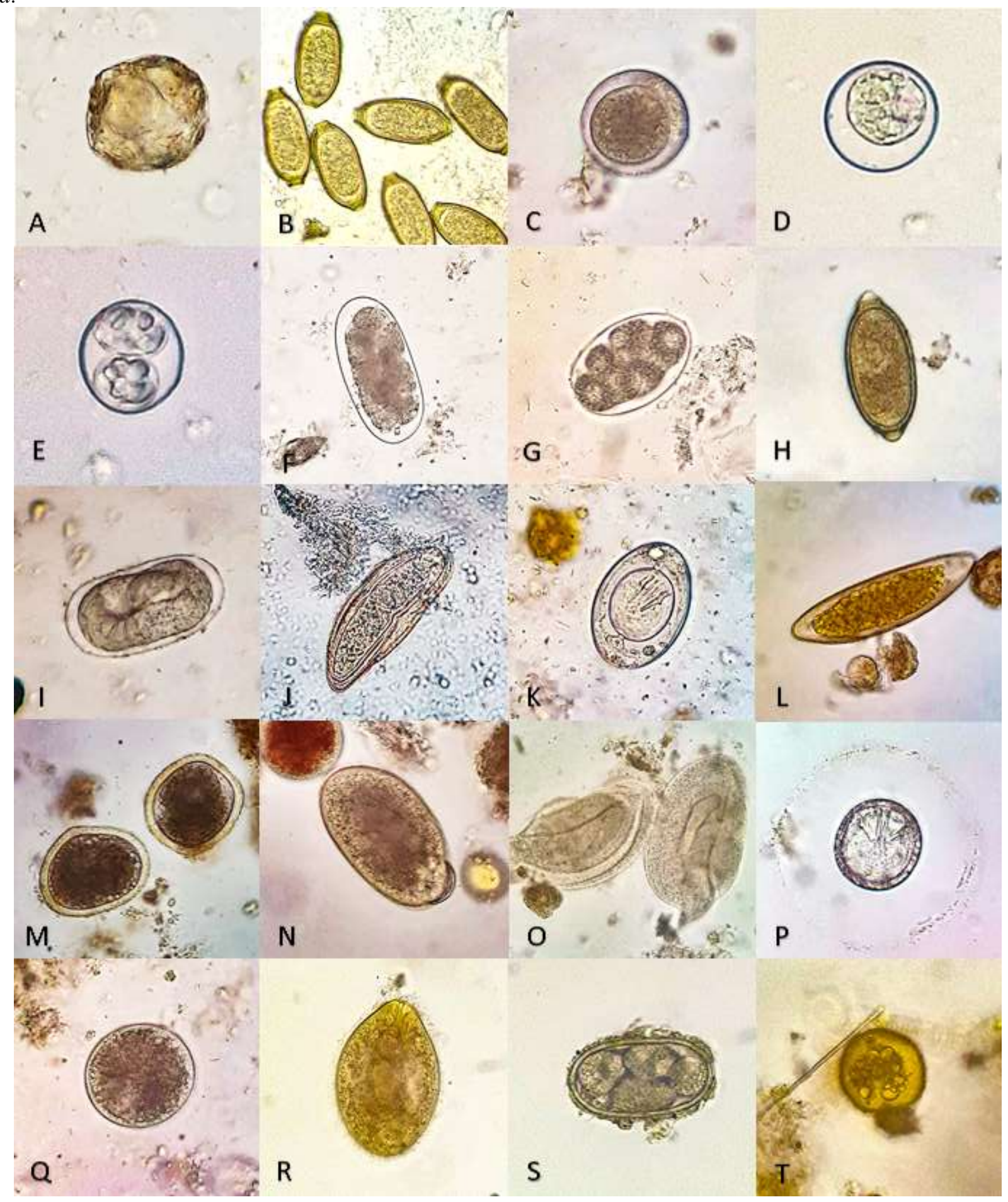

Source: Personal archive. 
Protozoans were found in $13.9 \%$ of the samples (05/36), with the taxa Coccidia (60\%), Cilliophora (60\%), and Amoebozoa (20\%) being recorded. Among the coccidians, non-sporulated oocysts were found, as well as Eimeria spp. and Isospora spp. The ciliates were represented by cysts and trophozoites of Balantidium sp. and Nyctotherus sp. In addition, the only Amoebozoa recorded were cysts of Entamoeba coli. Finally, the percentage related to mite eggs and adults in the fecal samples was $16.7 \%(06 / 36)$ (Table 2, Figure 2).

Among the carnivorous mammals, the amount of Toxocara sp. eggs found was 4 eggs (40 EPG) in Puma concolor and 40 eggs (400 EPG) in Puma yagouroundi. In addition, 1 egg (10 EPG) of Strongyloides sp. and 1 (10 LPG) Rhabditidatype larvae were recovered from Nasua nasua. All samples from Sapajus primates were positive for Strongyloides sp. eggs, Ancylostomatidae eggs, and Rhabditida-type larvae. In primates, Strongyloides sp. eggs ranging from 20 (200 EPG) to 84 (840 EPG) units were found in the genus Sapajus, and 14 (140 EPG) in the species Chlorocebus aeothiops. Regarding the Ancylostomatidae family, there was a range of 3 (30 EPG) to 20 eggs (200 EPG) obtained from primates of the genus Sapajus. The number of Rhabditida-type larvae ranged from 2 (20 EPG) to 7 (70 EPG) in this genus. In addition, 7 eggs (70 EPG) of Cestoda were recovered from Sapajus flavius and 11 eggs (110 EPG) of Bertiella spp. were found in Alouatta caraya (Table 2).

In the bird samples, there was a prevalence of Capillaria sp. eggs, with 14 (140 EPG) being found in Ara chloropterus, 18 (180 EPG) in A. ararauna, 24 (240 EPG) in Patagioenas picazuro, and 96 (96 EPG) in Amazona aestiva. In addition, 3 oocysts (30 OPG) of Isospora sp., 2 oocysts (20 OPG) of unsporulated coccidian, and 1 (10 LPG) Rhabditida-type larva were found in Cacicus cela; 3 Ascaridoidea-type eggs (30 EPG) in Crax fasciolata; and 3 eggs (30 EPG) of Trichuris sp. in Rupornis magnirostris. Among reptiles, we obtained Aspiculuris sp. eggs ranging from 2 (20 EPG) to 5 (50 EPG) units in snakes like Pantherophis guttatus and Bothrops erythromelas. Hymenolepis sp. eggs were also recovered, ranging from 1 (10 EPG) to 7 (70 EPG) units in P. guttatus. Regarding the lacertid samples, in Iguana iguana 17 cysts (170 CPG) of Entamoeba coli, 13 oocysts (130 OPG) of non-sporulated coccidia, and 12 oocysts (120 OPG) of Eimeria sp. were found; while in Salvator merianae, 6 eggs (60 EPG) of strongilids, 10 Rhabditida-type larvae (100 LPG), and 3 Strongyloidoidea-type (30 EPG) were recovered. The largest number of parasitic forms recovered in this study was of Balantidium sp., with 15 cysts (150 CPG) and 200 trophozoites (2000 TPG), obtained from Chelonoidis denticulata, an occurrence that was not observed for Chelonoidis sp., in which 5 cysts (50 CPG) and 4 trophozoites (40 TPG) were obtained. In addition, in the testudine samples we noticed 38 cysts (380 CPG) and 44 trophozoites (440 TPG) of Nyctotherus sp. obtained from C. denticulata, as well as only 3 trophozoites (30 TPG) from Chelonoidis sp.; 3 Strongylida-type eggs (30 OPG) from C. denticulata and Chelonoidis sp.; 6 Rhabditida-type larvae (60 LPG) from C. denticulata and only 3 (30 LPG) from Chelonoidis sp. (Table 2).

\section{Discussion}

Researches carried out in several countries, including Brazil, have been carried out to determine the occurrence of parasitism in wild animals in zoos by means of coproparasitological analysis. In general, Cystoisospora sp., Toxocara cati, Strongyloides stercoralis, Toxascaris leonina, and hookworms are commonly reported for mammalian carnivores. In artiodactyls, protozoans such as Eimeria spp. and Cryptosporidium spp., as well as nematodes such as Trichuris sp., Toxocara vitulorum, Strongyloides sp., and parasites of the Paramphistomidae family have also been observed. Eggs of the Ancylostomatidae family, Trichuris sp., Strongyloides sp., Prosthernorchis elegans, and Bertiella spp. have been found in primates. In Brazil, Capillaria spp., Ascaridia sp., Heterakis sp., Libyostrongylus spp., Raillietina spp., Eimeria spp., and Isospora spp. have already been reported in birds (Fagiolini et al., 2018, Marques et al., 2019).

Among the findings of this study, the first record of gastrointestinal endoparasites from Tapirus terrestris in Northeast Brazil stands out. This study reports the occurrence of non-sporulated oocysts of coccids, and cysts and trophozoites of 
Balantidium, both being reported for the first time in Brazil. Generally, infections by endoparasites in free-living tapirids are asymptomatic, but signs of parasitic disease have been observed in captive animals. We also highlight the first record of Bertiella spp. in Alouatta caraya in the Northeast, Brazil. Clinical signs of this parasitic disease have not been demonstrated for this primate species, but the importance of this zoonosis has been reported, which may occur mainly in patients with direct or indirect contact with these animals, resulting in abdominal discomfort, diarrhea, gastroenteritis, and anorexia (Oliveira et al., 2011; Fernandes-Santos et al., 2020).

Further, this is the first occurrence of Hymenolepis spp. and Aspiculuris spp. as spurious parasites from reptiles in Brazil, exhibiting pseudoparasitism in these animals from the moment they ingest rodents, which are the definitive hosts. Although these pseudoparasites do not infect them, reptiles can be regarded as dispersers of viable parasitic forms that may cause infection in their respective hosts, such as rodents, non-human primates, and humans. In addition, this study also highlights the parasitism by Entamoeba coli and Eimeria spp. in Iguana iguana. Although infection by the latter is usually asymptomatic, generally when Entamoeba coli affects the gastrointestinal system, it may cause necrotic enteritis, hepatitis and liver abscesses, lethargy, diarrhea, regurgitation, convulsions, depression, hematochezia, and death in Squamata (Rinaldi et al., 2012; Lima et al., 2017; 2021).

Despite the great relevance of Zoological Parks and the struggle of these institutions to maintain the health of their animals, implementing prevention, diagnosis, and treatment programs, it is well known that many captive animals are housed close to each other, making parasitic infections inevitable. In addition, captive animals are often under considerable stress, which decreases their immunity and makes them more susceptible to infections. These parasites can pose a serious threat to the captive animals, occasionally causing fatalities. Many of these diseases, besides interfering with the welfare of the host species and affecting considerably their birth and mortality rates, may be zoonotic, posing a risk to animal handlers and animal care workers. In the present case, there was still the aggravating factor of the enclosures being within a forest reserve, which favors a greater contact of the animals with the droppings of other individuals, or even with intermediate hosts (Fagiolini et al., 2010; Oliveira et al., 2011; Snak et al., 2014; Schieber, M.C.; Štrkolcová, 2019; Dashe; Behanu, 2020; Patra et al., 2020).

The parasitological diagnosis of wild and exotic animals kept in captivity is essential to assist decisions related to their treatment, since they provide important information about the health of the herd and the immune resistance of the hosts. In addition, this information collaborates with the scientific community and contributes to provide ecological data for each of the species herein studied, favoring their conservation and preservation (Barros et al., 2017).

Although there are previous works that have carried out parasitological surveys in animals from zoos in Brazil, these studies, besides being very scarce, are much spaced. Typically, these investigations did not evaluate most of the animals kept at those zoobotanic parks. The present research was the pioneer, in Brazil, to perform the parasitological diagnosis of most of the vertebrate animals of the same zoobotanic park, with species from the Mammalia, Aves, Archelosauria, and Lepidosauria taxa.

\section{Conclusions}

A total of $54.5 \%$ of the tested animals were parasitized, which represents a risk to the health of both humans and animals, since many of these pathogens are also of medical importance. This research helps to broaden the ecological data and assists in the ex-situ conservation of wild and exotic animals. Based on the knowledge generated by this study, additional work is possible in order to understand the ecology of these endoparasites in the animals herein studied; investigate the potential consequences that these hosts may face in the wild; and the way parasitism might affect the welfare of host species in captivity and in the wild. Finally, this study contributes to the knowledge of endoparasites that may occur in zoos in Brazil and specifically in the Northeast region of this country, as well as for the species studied here. 


\section{Acknowledgments}

We thank the Federal Rural University of the Semi-Arid (UFERSA) for the support in developing this research and the researchers from the Laboratory of Animal Parasitology (LPA-UFERSA) and the entire team of the Zoobotanical Park Arruda Câmara, in João Pessoa-PB, which were essential for this study.

\section{References}

Ayres, M. C. C., Peixoto, M. S. R., da Silva, W. B., Gomes, D. M., Nunes, O. C., Borges, K. B., \& de Almeida, M. A. O. (2016). Ocorrência de parasitos gastrintestinais em Psitacídeos, mantidos em Parques Ecológicos na região metropolitana de Salvador, Bahia. Brazilian Journal of Veterinary Medicine, 38(2), $133-136$.

Barros, L. A., Sant, L. X., \& Magalhães, B. S. N. (2017). Prevalência de parasitos gastrointestinais em mamíferos selvagens do Jardim Zoológico do Rio de Janeiro. Revista Brasileira de Ciência Veterinária, 24(4), 179-183.

Capasso, M., Maurelli, M. P., Ianniello, D., Alves, L. C., Amadesi, A., Laricchiuta, P., \& Rinaldi, L. (2019). Use of Mini-FLOTAC and Fill-FLOTAC for rapidly diagnosing parasitic infections in zoo mammals. Revista Brasileira de Parasitologia Veterinária, 28, $168-171$.

Cringoli, G., Rinaldi, L., Maurelli, M. P., \& Utzinger, J. (2010). FLOTAC: new multivalent techniques for qualitative and quantitative copromicroscopic diagnosis of parasites in animals and humans. Nature protocols, 5(3), 503-515.

Cringoli, G., Rinaldi, L., Albonico, M., Bergquist, R., \& Utzinger, J. (2013). Geospatial (s) tools: integration of advanced epidemiological sampling and novel diagnostics. Geospatial health, 7(2), 399-404.

Cringoli, G., Maurelli, M. P., Levecke, B., Bosco, A., Vercruysse, J., Utzinger, J., \& Rinaldi, L. (2017). The Mini-FLOTAC technique for the diagnosis of helminth and protozoan infections in humans and animals. Nature protocols, 12(9), 1723-1732.

Dashe, D., \& Berhanu, A. (2020). Study on Gastrointestinal Parasitism of Wild Animals in Captivity at the Zoological Garden of Haramaya University, Ethiopia. Open Journal of Veterinary Medicine, 10(9), 173-184.

Fagiolini, M., Lia, R. P., Laricchiuta, P., Cavicchio, P., Mannella, R., Cafarchia, C., \& Perrucci, S. (2010). Gastrointestinal parasites in mammals of two Italian zoological gardens. Journal of Zoo and Wildlife Medicine, 41(4), 662-670.

Fernandes-Santos, R. C., Medici, E. P., Testa-José, C., \& Micheletti, T. (2020). Health assessment of wild lowland tapirs (Tapirus terrestris) in the highly threatened Cerrado biome, Brazil. Journal of wildlife diseases, 56(1), 34-46.

Foreyt, W.J. (2002). Veterinary parasitology: reference manual. Blackwell Publishing Professional.

Hoffman, W. A.; Pons, J. A. \& Janer, J. L. (1934). The sedimentation-concentration method in schistosomiasis mansoni. Journal of Tropical Medicine and Public Health, 9 .

Hoffmann, R. P. (1987). Diagnóstico de parasitismo veterinário. Sulina.

Kvapil, P., Kastelic, M., Dovč, A., Bártová, E., Č́ížek, P., Lima, N., \& Štrus, Š. (2017). An eight-year survey of the intestinal parasites of carnivores, hoofed mammals, primates, ratites and reptiles in the Ljubljana zoo in Slovenia. Folia parasitologica, 64, 01-06.

Lima, V. F. S., Bezerra, T. L., Andrade, A. F. D., Ramos, R. A. N., Faustino, M. A. D. G., Alves, L. C., \& Meira-Santos, P. O. (2016). Gastrointestinal parasites of exotic birds living in captivity in the state of Sergipe, Northeastern Brazil. Revista Brasileira de Parasitologia Veterinária, $26,96-99$.

Lima, V. F. S., do Nascimento Ramos, R. A., Giannelli, A., Andrade, W. W. A., López, I. Y. T., do Nascimento Ramos, I. C., \& Alves, L. C. (2021). Ocorrência de parasitos gastrointestinais zoonóticos de roedores eo risco de infecção humana em diferentes biomas do Brasil. Brazilian Journal of Veterinary Medicine, 43(1), e113820-e113820.

Marques, S. M. T., Menetrier, L. D. C., Natal, A. C. C., Fernandes, L. S., Meyer, J., \& Alievi, M. M. (2019). Prevalência de parasitos intestinais em aves domésticas e silvestres do sul do Brasil. Revista Agrária Acadêmica. 2(5), 17-24.

Oliveira, S.G.; Prates, H. M., Mentz, M., \& Bicca-Marques, J. C. (2011). Prevalência de Bertiella sp. em um grupo de bugios-pretos, Alouatta caraya (Humbolt, 1812). In: Melo, F. R.; Mourthé, I. A. Primatologia no Brasil., Sociedade Brasileira de Primatologia.

Patra, G., Lalremruati, P., Ghosh, S., Parida, A., Kumar Borthakur, S., \& Behera, P. (2020). Prevalence of gastrointestinal parasites in captive non-human primates of zoological gardens in North-Eastern region of India. Biological Rhythm Research, 51(5), 690-698.

Reed, T. E., Daunt, F., Kiploks, A. J., Burthe, S. J., Granroth-Wilding, H. M., Takahashi, E. A., \& Cunningham, E. J. (2012). Impacts of parasites in early life: contrasting effects on juvenile growth for different family members. PLoS One, 7(2), e32236.

Rinaldi, L., Mihalca, A. D., Cirillo, R., Maurelli, M. P., Montesano, M., Capasso, M., \& Cringoli, G. (2012). FLOTAC can detect parasitic and pseudoparasitic elements in reptiles. Experimental Parasitology, 130(3), 282-284.

Schieber, M. C., \& Strkolcova, G. (2019). Prevalence of Endoparasites in Carnivores in a Zoo and a Wolves park in Germany. Folia Vet, 63, 54-59.

Snak, A., Lenzi, P. F., Agostini, K. M., Delgado, L. E., Montanucci, C. R., \& Zabott, M. V. (2014). Análises coproparasitológicas de aves silvestres cativas. Ciência Animal Brasileira, 15, 502-507.

Willis, H. H. (1921). A simple levitation method for the detection of hookworm ova. Medical Journal of Australia, 2(18). 